\title{
Catalytic Etherification of Glycerol with Alcohols
}

\author{
Modris Roze ${ }^{1}$, Valdis Kampars ${ }^{2}$, Kristine Teivena ${ }^{3}$, Ruta Kampare ${ }^{4}$, Edvards Liepins ${ }^{5}$ \\ ${ }^{1-4}$ Riga Technical University, ${ }^{5}$ Institute of Organic Synthesis
}

\begin{abstract}
Glycerol ethers could be the good fuel additives. In recent years, the etherification of glycerol has been widely investigated. We tried to perform the synthesis of glycerol ethers using different alcohols - ethanol, isopropanol, tert-butanol. Amberlyst-15, Amberlyst-36, Montmorillonite $\mathrm{K}$ 10, $\beta$-zeolite were used as catalysts. The etherification reaction between glycerol and alcohols was carried out under atmospheric pressure, by operating at different temperatures ranging from 60 ${ }^{\circ} \mathrm{C}$ to boiling temperatures, at different reaction times and at both different catalyst/glycerol and alcohol/glycerol rates. We also tried to perform this reaction using ultrasonic and microwave conditions. The best results were achieved, when toluene as a solvent and Amberlyst-36 as a catalyst were used.
\end{abstract}

Keywords: glycerol, isopropyl glycerol ether, tert-butyl glycerol ether, heterogeneous catalyst, etherification

\section{INTRODUCTION}

Biodiesel is fuel made from renewable resources, such as vegetable oils or animal fats, by transesterification. Biodiesel contributes less to global warming than fossils fuels due to the reduction of $\mathrm{CO}_{2}, \mathrm{CO}$ and hydrocarbon emissions from engines. It also decreases national dependence on imported fuels.

For many years, glycerol has mainly been produced from petrochemicals. In recent years, a huge increase in the production of biodiesel has led to the overproduction of glycerol and many synthetic production plants have been closed or reduced.

Therefore, the new uses for glycerol are searched. Now chemists are trying to use the glycerol as a building block for the production of value added products [1-3]. Glycerol is a source of various solvents, for example, glycerol ethers and esters, propylene glycols, glycerol carbonate, also some oxidation products (e.g., glyceric acid, ketomalonic acid) and other chemicals (e.g., acrolein). Oxygenated additive to the fuels is also a great opportunity for new uses of glycerol. Glycerol cannot be added directly to fuel due to its decomposition and polymerization at high temperatures, which leads to the damage of an engine. Glycerol must be modified to derivatives, which are compatible with diesel or biodiesel, prior being added to the fuel. Glycerol alkyl ethers could be good fuel additives. There are various research papers addressed to the production of alkyl ethers of glycerol [4-8]. The synthesis of glycerol tert-butyl ethers from isobutene and glycerol catalyzed by acidic homogenous catalysts (e.g., p-toluene sulfonic acid) and generally by heterogeneous catalysts, such as strong acid ion-exchange resins or zeolites, is widely investigated. The main problem is availability of isobutene and the need for autoclave.

The etherification of glycerol with alcohols was also investigated but mainly in an autoclave reactor [9-11].

In this study, we present some results of glycerol etherification by ethanol, isopropanol and tert-butanol in the presence of heterogenic catalysts - ion exchange resins, largepore zeolite and montmorillonite clay. Reaction was carried out in glass flasks under reflux in solvents or solvent-free conditions. The influence of catalyst concentration, mole ratio of alcohol/glycerol, microwave and ultrasonic irradiation were investigated.

\section{RESULTS AND DISCUSSION}

The synthesis of glycerol ethers was performed in the presence of Amberlyst 15, Amberlyst 36, $\beta$-zeolite (hydrogen form) and Montmorillonite K10 as catalysts without a solvent or in a toluene or 1,4-dioxane solution. Catalysts were used both in raw and pre-treated by heating at different temperatures with different processing time. Amberlyst 15 and Amberlyst 36 were heated at temperature of $120{ }^{\circ} \mathrm{C}$ for 10 hours, $\beta$-zeolite at $400{ }^{\circ} \mathrm{C}$ for 4 hours, Montmorillonite $\mathrm{K} 10$ at $200{ }^{\circ} \mathrm{C}$ for 2 hours. The samples of reaction products were analysed by thin-layer and gas-liquid chromatography, and the structure was determined by NMR spectroscopy. Products were separated by fractional vacuum distillation. If necessary, the compounds were purified by column chromatography using silica gel as an adsorbent and ethylacetate as an eluent.

Etherification of glycerol with ethanol failed. We obtained only a small amount (2-3\%) of the desired products. Attempts to increase the glycerol conversion varying different catalysts, their amount and the reaction time were not successful.

The main product of isopropanol reaction with glycerol is 3-alkoxypropane-1,2-diol (1a). The yield of 1,3dialkoxypropane-2-ol (3a) amount is less than 10\%. After vacuum distillation, we obtained compounds (1a, 3a) with purity of $95-97 \%$. Flash chromatography gave these compounds with purity more than $98 \%$.

In the gas-liquid chromatograms of reaction mixture, two additional peaks were found in small quantities, 2-5\% (peak area). Attempts to separate these compounds were unsuccessful, but we thought that these compounds were 2alkoxypropane-1,3-diol and 1,2-dialkoxypropane-3-ol. 
<smiles>[R]CC([R])C[R20]</smiles>

$\mathrm{R}=\mathrm{CH}\left(\mathrm{CH}_{3}\right)_{2}$ (a), $\mathrm{C}\left(\mathrm{CH}_{3}\right)_{3}$ (b)

Scheme 1. Reaction of glycerol with alcohols

TABLE 1

ETHERIFICATION OF GLYCEROL WITH ISOPROPANOL AND TERT-BUTANOL WITHOUT A SOLVENT

\begin{tabular}{|c|c|c|c|c|c|c|}
\hline No. & $\begin{array}{c}\text { Alcohol } \\
\text { (molar ratio to } \\
\text { glycerol) }\end{array}$ & $\begin{array}{c}\text { Catalyst } \\
\text { (wt \% to glycerol) }\end{array}$ & $\begin{array}{l}\text { Tempe- } \\
\text { rature } \\
\left({ }^{\circ} \mathrm{C}\right)\end{array}$ & $\begin{array}{l}\text { Yield of } \\
\text { alkyl } \\
\text { ethers }(\%)\end{array}$ & $\begin{array}{c}\text { Glycerol } \\
\text { conversion }(\%)\end{array}$ & $\begin{array}{l}\text { Glycerol alkyl } \\
\text { ether composition } \\
(\%)\end{array}$ \\
\hline 1 & Isopropanol(4) & Amberlyst 15 (5) & 82 & 14 & 17 & 1a $\sim 94$ \\
\hline 2 & Isopropanol(4) & Amberlyst 15 (6) & 82 & 16 & n.d. & $\mathbf{1 a} \sim 95$ \\
\hline 3 & Isopropanol(4) & Amberlyst 15(10) & 82 & 20 & 26 & $\mathbf{1 a} \sim 96$ \\
\hline 4 & Isopropanol(4) & Amberlyst 15 (12) & 82 & 19 & n.d. & $\mathbf{1 a} \sim 95$ \\
\hline 5 & Isopropanol(4)* & Amberlyst 15 (12) & 82 & 18 & 21 & $\mathbf{1 a} \sim 95$ \\
\hline 6 & Isopropanol(4)** & Amberlyst 15 (10) & 82 & 19 & n.d. & $\mathbf{1 a} \sim 95$ \\
\hline 7 & Tert-butanol (4) & Amberlyst 15 (10) & 83 & 22 & n.d. & $\begin{array}{l}\mathbf{1} \mathbf{b} \sim 93 \\
\mathbf{3 b} \sim 3\end{array}$ \\
\hline 8 & Tert-butanol (4) * & Amberlyst 15 (10) & 83 & 21 & n.d. & $\begin{array}{l}\mathbf{1} \mathbf{b} \sim 93 \\
\mathbf{3 b} \sim 3\end{array}$ \\
\hline 9 & Tert-butanol (4) & Montmorillonite K10 (6) & 83 & 33 & 40 & $\begin{array}{c}\mathbf{1 b} \sim 92 \\
\mathbf{3 b} \sim 4\end{array}$ \\
\hline 10 & Tert-butanol (4) & Zeolite $\beta$ hydr. (6) & 83 & 12 & n.d. & $\begin{array}{c}\mathbf{1} \mathbf{b} \sim 91 \\
\mathbf{3 b} \sim 4\end{array}$ \\
\hline 11 & Tert-butanol (4) & Amberlyst 36 (10) & 83 & 36 & 43 & $\begin{array}{c}\mathbf{1 b} \sim 93 \\
\mathbf{3 b} \sim 4\end{array}$ \\
\hline 12 & Tert-butanol (4) & Amberlyst 36 (5.5) & 83 & 40 & 43 & $\begin{array}{c}\mathbf{1} \mathbf{b} \sim 94 \\
\mathbf{3 b} \sim 4\end{array}$ \\
\hline 13 & Tert-butanol** (4) & Amberlyst 15 (10) & 83 & 20 & n.d. & $\begin{array}{c}\mathbf{1} \mathbf{b} \sim 91 \\
\mathbf{3 b} \sim 3\end{array}$ \\
\hline 14 & Tert-butanol (4) *** & Amberlyst 15 (10) & 83 & 4 & n.d. & $\begin{array}{c}\mathbf{1} \mathbf{b} \sim 93 \\
\mathbf{3 b} \sim 3\end{array}$ \\
\hline
\end{tabular}

Etherification of glycerol with isopropanol without a solvent over Amberlyst-15 as a catalyst in various amounts resulted in the formation of monoether $1 \mathbf{a}$ in the yield of 14 $20 \%$. Small amount of impurities of other products $3-6 \%$ was obtained. The glycerol conversion was only $17-26 \%$ (Table 1). Attempts to separate other reaction products in the pure form failed. The results revealed that it was not necessary to use a catalyst over $10 \%$ since neither glycerol conversion nor product yield or selectivity significantly changed. Also a long reaction time (24 hours) did not increase the glycerol conversion or the product yield. 
TABLE 2

ETHERIFICATION OF GLYCEROL WITH TERT-BUTANOL IN A SOLUTION

\begin{tabular}{|c|c|c|c|c|c|c|c|}
\hline No. & $\begin{array}{c}\text { Alcohol } \\
\text { (molar ratio to } \\
\text { glycerol \%) }\end{array}$ & Solvent & $\begin{array}{c}\text { Catalyst } \\
\text { (wt \% to glycerol) }\end{array}$ & $\begin{array}{l}\text { Tempe- } \\
\text { rature } \\
\left({ }^{\circ} \mathrm{C}\right)\end{array}$ & $\begin{array}{l}\text { Yield } \\
\text { of } \\
\text { alkyl } \\
\text { ethers } \\
(\%)\end{array}$ & $\begin{array}{c}\text { Glycerol } \\
\text { conversion } \\
(\%)\end{array}$ & $\begin{array}{c}\text { Glycerol } \\
\text { alkyl ether } \\
\text { composition } \\
(\%)\end{array}$ \\
\hline 1 & Tert-butanol (4) & toluene & Amberlyst 15 (5) & 82 & 53 & 63 & 1b $\sim 92$ \\
\hline 2 & Tert-butanol (4) & toluene* & Amberlyst 15 (5) & 82 & 49 & 73 & $\mathbf{1 b} \sim 91$ \\
\hline 3 & Tert-butanol (4) & toluene & Amberlyst 15 (3) & 82 & 50 & 60 & 1b $\sim 94$ \\
\hline 4 & Tert-butanol(4) & toluene & Amberlyst 36 (5) & 82 & 59 & n.d. & $\mathbf{1 b} \sim 93$ \\
\hline 5 & Tert-butanol (4) & toluene & Amberlyst 36 (3) & 82 & 64 & 70 & $\mathbf{1 b} \sim 95$ \\
\hline 6 & Tert-butanol (4) & toluene & Amberlyst 15 (10) & 82 & 45 & n.d. & $\mathbf{1 b} \sim 90$ \\
\hline 7 & Tert-butanol(4) & dioxane & Amberlyst 15 (5) & 83 & 44 & n.d. & $\mathbf{1 b} \sim 92$ \\
\hline 8 & Tert-butanol (4) & toluene & Montmorillonite K10 (5) & 83 & 43 & 58 & $\begin{array}{l}\mathbf{1 b} \sim 92 \\
\mathbf{3 b} \sim 3\end{array}$ \\
\hline 9 & Tert-butanol (4) & toluene & Zeolite $\beta$ hydr.** (6) & 83 & 5 & n.d. & n.d. \\
\hline 10 & Tert-butanol (4) & ethanol & Amberlyst 15 (5) & 83 & 4 & n.d. & n.d. \\
\hline 11 & Tert-butanol (4) & toluene & Amberlyst $15 * * *(5)$ & 83 & 0 & n.d. & n.d. \\
\hline
\end{tabular}

The main product of glycerol etherification with tert-butanol was monoether $\mathbf{1 b}$. The yield of the ether $\mathbf{1 b}$ depending on reaction conditions varied from 4 to $40 \%$. The best result $(40 \%$ yield) was achieved when Amberlyst 36 as a catalyst in 5.5 wt.\% to glycerol was used (Table 1). Attempts to improve glycerol conversion by microwave or ultrasonic irradiation failed in both cases. Irradiation accelerated the reaction, but the conversion rate of glycerol or product yield did not change significantly. Maximum of glycerol conversion in the case of isopropanol was achieved after 40-50 minutes, but in the case of tert-butanol reaction after 30-45 minutes and then the reaction stopped.

Water could inhibit the reaction, therefore the use of preliminary dried catalyst and alcohol was tried, but it increased the conversion of glycerol only insignificantly. Attempts to add water removing substances, such as molecular sieves, also did not give the expected results, and glycerol conversion was low. Another reaction was performed in the solution of toluene, which at the same time works as a water removing agent. It was observed that the addition of toluene to glycerol in the ratio 5-6: 1 and the use of a Dean-Stark trap significantly increased the conversion of glycerol. Four catalysts - Amberlyst 15, Amberlyst 36, Montmorillonite K10, Zeolite $\beta$ - were tested. The best result was achieved when Amberlyst 36 (3\% wt. \% to glycerol) was used as a catalyst, glycerol: tert-butanol: toluene ratio was 1:4:6 and the reaction time was 3 hours. Glycerol conversion in this case was $\sim 67 \%$ and the yield of 3-tertbutoxypropane-1,2-diol (1b) was $60 \%$. Under these reaction conditions, Amberlyst 15 and Montmorillonite K10 were less active. Yields of alkylethers 1b, 3b were $54 \%$ and $43 \%$, respectively. Unworked Zeolite $\beta$ did not show any catalytic activity after heating at 320 ${ }^{\circ} \mathrm{C}$ for 4 hours. Zeolite $\beta$ showed a very low activity. Also wet Amberlyst 15 was inactive. It was found that in the tert-butanol reaction with glycerol, the ratio of monoalkylglycerol: dialkylglycerol amount depended on the catalyst concentration and the reaction time. Extension of the reaction time from 2 to 8 hours increased the conversion of glycerol from $63 \%$ to $73 \%$ (Table 2), but the yield of glycerol ethers decreased and additionally we found oligoglycerols in the yield of $2-5 \%$. These products were not separated, but according to NMR a mixture of different oligoglycerols was formed. It was observed that isobutene was also produced, i.e., a reversible reaction took place and led to a decrease in the yields of alkylglycerols. An increase in the amount of catalyst Amberlyst 15 to $10 \mathrm{wt} \%$ did not lead to a higher yield of alkylethers $\mathbf{1 b}, \mathbf{3 b}$, but only increased the speed of the reaction.

The catalysts, Amberlyst 15 and Amberlyst 36, were separated, and after washing with water, ethanol and drying at $110{ }^{\circ} \mathrm{C}$ they were re-used. The observed catalytic activity for the recycled catalysts was the same as a new one.

Two other solvents 1,4-dioxane and ethanol were tested. Yield of glycerol ethers in solution of 1,4-dioxane compared with toluene was slightly lower and reached only $44 \%$. Ethanol was an unsuitable solvent for glycerol etherification. In this case, the yield was only $2-4 \%$. From these studies we can conclude that the choice of a solvent is essential and, to a considerable extent, it influences the etherification reaction.

Glycerol monoethers 1a, $\mathbf{1 b}$ and diether $\mathbf{3 b}$, which were not available commercially, were isolated from the reaction products by vacuum distillation, followed by column chromatography and identified by ${ }^{13} \mathrm{C}-\mathrm{NMR}$ and ${ }^{1} \mathrm{H}-\mathrm{NMR}$ spectrometry [12]. Data of ${ }^{13} \mathrm{C}-\mathrm{NMR}$ and ${ }^{1} \mathrm{H}-\mathrm{NMR}$ spectra for compounds 1a, $\mathbf{1 b}, \mathbf{3 b}$ are summarized in Tables 3 and 4. IR spectrometry was used to identify ethers $\mathbf{1 b}, \mathbf{3 b}$, but unfortunately, spectra were too complicated to interpret.

\section{EXPERIMENTAL SECTION}

\section{Materials}

All reagents and solvents were of reagent quality and obtained from commercial suppliers. Amberlyst 15 hydrogen form dry, Amberlyst 36 and Montmorillonite K-10 from Sigma-Aldrich, Zeolite $\beta$, hydrogen powder from Alfa Aesar, Amberlyst 15 wet 
from Acros Organics, glycerol, isopropanol, tert-butanol, toluene, 1,4-dioxane from Roth. Silica gel 60 purchased from Rocc. Amberlyst 15 and Amberlyst 36 was heated at the temperature of $120{ }^{\circ} \mathrm{C}$ for 10 hours, $\beta$-zeolite at $400{ }^{\circ} \mathrm{C}$ for 4 hours, Montmorillonite $\mathrm{K} 10$ at $200^{\circ} \mathrm{C}$ for 2 hours.

\section{Measurements}

IR spectra (thin films) were recorded on a Thermo-Nicolet 5700 spectrometer. ${ }^{13} \mathrm{C}-\mathrm{NMR}$ spectra and ${ }^{1} \mathrm{H}-\mathrm{NMR}$ spectra were recorded using Bruker $300 \mathrm{MHz}(\mathrm{J}, \mathrm{Hz})$ spectrometer or Varian UNITY INOVA $600 \mathrm{MHz}$ spectrometer equipped with a cryoprobe in $\mathrm{CDCl}_{3}$ - solution at $25{ }^{\circ} \mathrm{C}$. Chemical shifts are reported in ppm relative to a residual solvent signal $\left(\delta\left({ }^{1} \mathrm{H}\right) 7.26\right.$ ppm, $\left.\delta\left({ }^{13} \mathrm{C}\right) 77.16 \mathrm{ppm}\right)$.

Assignment of the carbon atom of $\mathrm{CH}, \mathrm{CH}_{2}, \mathrm{CH}_{3}$ and quaternary carbon atoms were identified by the ${ }^{13} \mathrm{C}$ - $\mathrm{NMR}$ (APT) spectra and ${ }^{1} \mathrm{H}-{ }^{13} \mathrm{C}$ HSQCEDETGP experiments. GC analyses were performed on a dual channel Agilent Technologies 7890 gas chromatograph equipped with Innowax $30 \mathrm{~m} \times 0.25 \mathrm{~mm} \times 0.25 \mu \mathrm{m}$ column. TLC chromatography was carried out on TLC plates Alugram SIL G purchased from Roth. Visualization was achieved by basic $\mathrm{KMnO}_{4}$ solution or by iodine vapours.

\section{Synthesis}

\section{Typical Procedure for the Synthesis under Solvent-free Conditions}

In a three neck flask equipped with a magnetic stirrer, thermometer, reflux condenser $23 \mathrm{~g}(0.25 \mathrm{~mol})$ of glycerol, $74 \mathrm{~g}$ (1 mol) of tert-butanol and $2.3 \mathrm{~g}$ of Amberlyst 15 catalyst were placed. The mixture was heated under reflux and stirred for 2 hours. The reaction mixture was cooled down and filtered to a separate catalyst. The excess of tert-butanol was evaporated under reduced pressure and the remaining yellowish oil was subjected to fractional vacuum distillation. The first fraction was collected at $85-105^{\circ} \mathrm{C}(2-4$ mbar), and the second fraction at $120-130{ }^{\circ} \mathrm{C}(2-4 \mathrm{mbar})$. The first fraction contained glycerol ether $\mathbf{1 b}(93-94 \%)$ and $\mathbf{3 b}(3-4 \%)$, the second one mainly pure glycerol. To separate the glycerol ethers $\mathbf{1 b}\left(\mathrm{R}_{\mathrm{f}} 0.4\right)$ and $\mathbf{3 b}\left(\mathrm{R}_{\mathrm{f}}\right.$ 0.8 ), the first fraction was chromatographed by flash chromatography (silica gel 60, ethylacetate). Ethers 1a, 1b, 3b were obtained with a purity $>98 \%$. Samples of products were analysed by thin-layer and gas-liquid chromatography.

TABLE 3

THE ${ }^{1}$ H CHEMICAL SHIFTS OF GLYCEROL ETHERS

\begin{tabular}{|c|c|c|c|c|c|c|c|c|}
\hline $\begin{array}{l}\text { Glycerol } \\
\text { ether }\end{array}$ & $\mathrm{C}(3) \mathbf{H}_{2}$ & $\mathrm{C}(2) \mathbf{H}$ & $\mathrm{C}(1) \mathbf{H}_{2}$ & \multicolumn{3}{|c|}{ Proton of ether group } & \multicolumn{2}{|c|}{$\mathrm{OH}$} \\
\hline & & & & $\begin{array}{l}\mathrm{CH}_{3} \\
\text { (3) }\end{array}$ & $\begin{array}{r}\mathrm{CH}_{3} \\
\text { (1) }\end{array}$ & $\mathrm{CH}$ & $\mathrm{C}(2)$ & $\mathrm{C}(1)$ \\
\hline $1 \mathrm{~b}$ & $\begin{array}{c}\mathbf{3 . 3 4}(\mathrm{dd}) 1 \mathrm{H} \\
{ }^{2} \mathrm{~J}=9.2 \mathrm{~Hz}, \\
{ }^{3} \mathrm{~J}=4.7 \mathrm{~Hz} \\
\mathbf{3 . 3 2}(\mathrm{dd}) 1 \mathrm{H} \\
{ }^{2} \mathrm{~J}=9.2 \mathrm{~Hz}, \\
\mathrm{~J}=6.0 \mathrm{~Hz}\end{array}$ & $\begin{array}{l}3.71 \\
(\mathrm{~m})\end{array}$ & $\begin{array}{c}\mathbf{3 . 6 0} \\
{ }^{2} \mathrm{~J}=10.4 \mathrm{~Hz} \\
{ }^{3} \mathrm{~J}=3.6 \mathrm{HZ} \\
\mathbf{3 . 5 1} \\
{ }^{2} \mathrm{~J}=10.4 \mathrm{~Hz} \\
{ }^{3} \mathrm{~J}=4.6 \mathrm{~Hz}\end{array}$ & 1.11 & - & - & 3.65 & 3.57 \\
\hline $\mathbf{3 b}$ & $\begin{array}{c}\mathbf{3 . 3 7}(\mathrm{dd}) \\
{ }^{2} \mathrm{~J}=9.0 \mathrm{~Hz}, \\
{ }^{3} \mathrm{~J}=5.2 \mathrm{~Hz} \\
\mathbf{3 . 3 2}(\mathrm{dd}) \\
{ }^{2} \mathrm{~J}=9.0 \mathrm{~Hz} \\
{ }^{3} \mathrm{~J}=5.8 \mathrm{~Hz}\end{array}$ & $\begin{array}{l}3.74 \\
(\mathrm{~m})\end{array}$ & $\begin{array}{c}\mathbf{3 . 3 7}(\mathrm{dd}) \\
{ }^{2} \mathrm{~J}=9.0 \mathrm{~Hz} \\
{ }^{3} \mathrm{~J}=5.2 \mathrm{~Hz} \\
\mathbf{3 . 3 2}(\mathrm{dd}) \\
{ }^{2} \mathrm{~J}=9.0 \mathrm{~Hz} \\
{ }^{3} \mathrm{~J}=5.8 \mathrm{~Hz}\end{array}$ & 1.14 & 1.14 & - & 2.58 & - \\
\hline $1 \mathbf{a}$ & $\begin{array}{c}\mathbf{3 . 4 7}(\mathrm{dd}) \\
{ }^{2} \mathrm{~J}=9.7 \mathrm{~Hz} \\
{ }^{3} \mathrm{~J}=4.5 \mathrm{~Hz} \\
\mathbf{3 . 4 2}(\mathrm{dd}) \\
{ }^{2} \mathrm{~J}=9.7 \mathrm{~Hz} \\
{ }^{3} \mathrm{~J}=6.2 \mathrm{~Hz}\end{array}$ & $3.78(\mathrm{~m})$ & $\begin{array}{c}\mathbf{3 . 6 5}(\mathrm{dd}) \\
{ }^{2} \mathrm{~J}=11.5 \mathrm{~Hz}, \\
{ }^{3} \mathrm{~J}=3.7 \mathrm{~Hz} \\
\mathbf{3 . 5 5}(\mathrm{dd}) \\
{ }^{2} \mathrm{~J}=11.5 \mathrm{~Hz}, \\
{ }^{3} \mathrm{~J}=5.8 \mathrm{~Hz}\end{array}$ & $\begin{array}{c}\mathbf{1 . 1 4}(\mathrm{d}) \\
{ }^{3} \mathrm{~J}=6.2 \mathrm{~Hz}\end{array}$ & & $\begin{array}{l}\mathbf{3 . 5 7} \\
(\mathrm{m})\end{array}$ & & \\
\hline
\end{tabular}

TABLE 4

THE ${ }^{13}$ C CHEMICAL SHIFTS OF GLyCEROL ETHERS

\begin{tabular}{|c|c|c|c|c|c|c|c|c|c|}
\hline \multirow{2}{*}{$\begin{array}{l}\text { Glycerol } \\
\text { ether }\end{array}$} & \multirow{2}{*}{${ }^{13} \mathrm{C}(1) \mathrm{H}_{2}$} & \multirow[t]{2}{*}{${ }^{13} \mathrm{C}(2) \mathrm{H}$} & \multirow{2}{*}{${ }^{13} \mathrm{C}(3) \mathrm{H}_{2}$} & \multicolumn{2}{|c|}{${ }^{13} \mathbf{C}\left(\mathrm{CH}_{3}\right)_{3}$ at } & \multicolumn{2}{|c|}{$\begin{array}{c}\mathrm{C}\left({ }^{13} \mathrm{CH}_{3}\right)_{3} \\
\text { at }\end{array}$} & \multirow{2}{*}{ 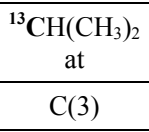 } & \multirow{2}{*}{$\begin{array}{c}\mathrm{CH}\left({ }^{13} \mathrm{CH}_{3}\right)_{2} \\
\text { at }\end{array}$} \\
\hline & & & & $\mathrm{C}(3)$ & $\mathrm{C}(1)$ & $\mathrm{C}(3)$ & $\mathrm{C}(1)$ & & \\
\hline $1 b$ & 64.2 & 70.9 & 63.4 & 73.4 & - & 27.3 & - & - & - \\
\hline $\mathbf{3 b}$ & 62.8 & 70.1 & 62.8 & 73.0 & 73.0 & 27.5 & 27.5 & - & - \\
\hline 1a & 63.9 & 70.9 & 69.5 & - & - & - & - & 72.4 & \\
\hline
\end{tabular}




\section{Typical Procedure for the Synthesis in the Solvent Containing Media}

In a three neck flask equipped with a magnetic stirrer, thermometer, condenser $23 \mathrm{~g}(0.25 \mathrm{~mol})$ glycerol, $74 \mathrm{~g}(1$ mol) tert-butanol $2.3 \mathrm{~g}$ Amberlyst 15 catalyst and $130 \mathrm{ml}$ of toluene were placed. The mixture was heated under reflux and stirred for 2 hours. The reaction mixture was cooled down and filtered to a separate catalyst. Toluene and excess of tert-butanol were evaporated under reduced pressure and the yellowish oil was subjected to fractional vacuum distillation. The first fraction was collected at $85-105^{\circ} \mathrm{C}(2$ 4 mbar), the second one at $120-130{ }^{\circ} \mathrm{C}(2-4 \mathrm{mbar})$. The first fraction contained glycerol ethers $\mathbf{1 b}$ and $\mathbf{3 b}$ (93-94\%), and the second one contained mainly pure glycerol. To separate glycerol ethers $\mathbf{1 b} \quad\left(\mathrm{R}_{\mathrm{f}} \quad 0.4\right)$ and $\mathbf{3 b}$ $\left(\mathrm{R}_{\mathrm{f}} 0.8\right)$, the first fraction was chromatographed by flash column chromatography (silica gel 60, ethylacetate).

\section{CONCLUSIONS}

The catalysts, Amberlyst 15, Amberlyst 36, Montmorillonite K-10, Zeolite $\beta$, supported the etherification of glycerol with tert-butanol and, as a result, the mixture of products was formed. Main product of reaction was 3alkoxypropane-1,2-diol (1a, b).

The 1,3-Dialkoxypropane-2-ol (3a, b) was also formed, but the yield did not exceed $10 \%$. The best results were achieved with a catalyst Amberlyst 36. The implementation of reaction in toluene significantly increased the glycerol conversion and yield of glycerol ethers. Microwave and ultrasound irradiation accelerated the reaction, but the conversion rate of glycerol or product yield did not change significantly. The catalysts, Amberlyst 15, Amberlyst 36, can be re-used more than three times without any loss of activity.

${ }^{13} \mathrm{C}$-NMR and ${ }^{1} \mathrm{H}$-NMR spectra are valid to identify and characterize the glycerol alkylethers. Thin-layer and gasliquid chromatography allowed controlling and optimizing the etherification reaction of glycerol.

\section{ACKNOWLEDGEMENTS}

The research has been supported by the European Social Fund Project "Scientific Group Supporting Latvian Activities of the European Strategic Energy Technology Plan”, No. 1DP/1.1.1.2.0/09/APIA/ VIAA/027.

\section{REFERENCES}

1. Rahmat, N., Abdullah, A.Z., Mohamed, A.R. Recent progress on innovative and potential technologies for glycerol transformation into fuel additives: a critical review. Renewable and Sustainable Energy Reviews, 2010, vol.14, p. 987-1000. http://dx.doi.org/10.1016/j.rser.2009.11.010

2. Frusteri, F., Arena, F., Bonura, G., Cannilla, C., Spadaro, L., Di Blasi, O. Catalytic etherification of glycerol by tert-butyl alcohol to produce oxygenated additives for diesel fuel Applied Catalysis A: General, 2009, vol. 367, p. 77-83. http://dx.doi.org/10.1016/i.apcata.2009.07.037

3. Behr, A., Gomes, J.P. The refinement of renewable resources: New important derivatives of fatty acids and glycerol Eur. J. Lipid. Sci. Technol., 2010, vol. $112, \quad$ p. $31-50$. http://dx.doi.org/10.1002/ejlt.200900091

4. Lee, H.J., Seung, D., Jung, K.S., Kim, H., Filimonov, I.N.
Etherification of glycerol by isobutylene: tuning the product composition. Applied Catalysis A: General, 2010, vol. 390, p. 235244. http://dx.doi.org/10.1016/j.apcata.2010.10.014

5. Klepacova, K., Mravec, D., Bajus, M. Tert-butylation of glycerol catalyzed by ion-exchange resins Applied Catalysis A: General, 2005, vol. 294, p. 141-147. http://dx.doi.org/10.1016/j.apcata.2005.06.027

6. Klepacova, K., Mravec, D., Kaszonyi, A., Bajus, M. Etherification of glycerol and ethylene glycol by isobutene. Applied Catalysis A: General, 2007, vol.328, p. http://dx.doi.org/10.1016/j.apcata.2007.03.031

7. Klepacova, K., Mravec, D., Hajekova, E., Bajus, M. Etherification of glycerol. Petroleum and Coal, 2003, vol. 45, p. 54-57.

8. Ozbay, N., Oktar, N., Dogu, G., Dogu, T. Conversion of biodiesel by-product glycerol to fuel ethers over different solid acid catalysts. International Journal of Chemical Reactor Engineering, 2010, vol. 8, p. A18. http://dx.doi.org/10.2202/1542-6580.2149

9. Chang, J.S., Chen, D.H. Optimization on the etherification of glycerol with tert-butyl alcohol. Journal of the Taiwan Institute of Chemical Engineers, 2011, vol. 42, p. 760-767. http://dx.doi.org/10.1016/j.jtice.2011.02.011

10. Klepacova, K., Mravec, D., Bajus, M. Etherification of glycerol with tert-butyl alcohol catalyzed by ion-exchange resins. Chemical Papers, 2006, vol.60, p. 224-230. http://dx.doi.org/10.2478/s11696-006-0040-x

11. Kiatkittipong, W., Intaracharoen, P., Laosiripojana, N., Chaisuk, C., Praserthdam, P., Assabumrungrat, S. Glycerol ethers synthesis from glycerol etherification with tert-butyl alcohol in reactive distillation Computers and Chemical Engineering, 2011, vol. 35, p. 2034-2043. http://dx.doi.org/10.1016/j.compchemeng.2011.01.016

12. Jamroz, M.E., Jarosz, M., Witowska-Jarosz, J., Bednarek, E., Tecza, W.,Jamroz M.H. et al. Mono-, di, and tri-tert-butyl ethers of glycerol. A molecular spectroscopic study. Spectrochimica Acta-Part A: Molecular and Biomolecular Spectroscopy, 2007, vol. 67, p.980-98. http://dx.doi.org/10.1016/j.saa.2006.09.017

Modris Roze, Dr.chem, Leading Researcher at Riga Technical University, the Faculty of Materials Science and Applied Chemistry, Institute of Applied Chemistry. Education: Qualification - Engineer-chemist, the Faculty of Chemistry of Riga Polytechnical Institute (Riga Technical University), Candidate of Chemical Sciences, 1977. Research is focused on biofuel synthesis, studies of electroactive condensed organic systems, phthalocyanines. He is a member of the Society of Porphyrins and Phthalocyanines. M.Roze delivers lecture courses at Riga Technical University: Industrial Organic Chemistry.

Address: Azenes 14/24, Riga, LV-1048, Latvia

Phone: +371708921

E-mail: mroze@ktf.rtu.lv

Valdis Kampars, Dr.habil.chem, the Head of the Institute of Applied Chemistry, Prof., Leading Researcher at Riga Technical University, the Faculty of Materials Science and Applied Chemistry. He is the author of more than 380 research publications in the field of synthesis and investigation of chromophores for energy conversion and information technology and in the field of synthesis and investigation of biofuels. He is the Project Director and Assistant Director of international collaborative and national scientific projects. V.Kampars delivers lecture courses at Riga Technical University: Structure of Matter, Fuels and Lubricants, Atomic Spectroscopy, Molecular Spectroscopy, Chemical Analysis. He is a full member of the Latvian Academy of Sciences.

Address: 14/24 Azenes Street, Riga, LV-1048, Latvia

E-mail: Valdis.Kampars@rtu.lv

Kristine Teivena, received her Mg.sc.ing. in 2012 from Riga Technical University. At present, she is a Researcher at Riga Technical University, the Faculty of Materials Science and Applied Chemistry. Her research is focused on the synthesis of derivatives of grapheme.

Address: 14/24 Azenes Str., Riga, LV-1048, Latvia

Phone: +3717089248

Ruta Kampare, Master of Science in Chemical Sciences, 1971. Education: 1966-1971, Riga Polytechnical Institute, the Faculty of Chemistry. Experience: in the period of 1971-1973 she was a Senior Laboratory Assistant; in the period of 1973-1995 she worked as a Senior Engineer at the Department of Organic Chemistry; from 1995 to 2006 she worked as a Quality Inspector at Lavijas Balsams JSC. Since 2007 she has been a 
Researcher at the Institute of Applied Chemistry (Riga Technical University). Research is focused on the studies of biofuels, their byproducts and NMR spectroscopy.

Address: Azenes 14/24, Riga, LV-1048, Latvia

Phone: +371 29443106

E-mail:ruta@ktf.rtu.lv

Edvards Liepins, Professor, Dr.hab.chem. Education: Dr.habil.chem. (Doctor of Science in the former USSR, the Latvian Academy of Sciences), 1985; Dr.chem. (Candidate of Sciences in the former USSR, Ph.D. in Western Countries), Riga Technical University, 1975; Riga Technical University (the Faculty of Chemistry), cum laude, 1971. Experience: he was an Engineer at Sloka Paper mill factory, Latvia, in the period of 1964-1968; he has been a Leading Researcher at the Latvian Institute of Organic Synthesis since 1968; he worked as a Researcher at the Swiss Federal
Institute of Technology (ETH), Zurich, Switzerland, in 1993; he was a Lecturer at the Department of Medical Biochemistry and Biophysics, the Royal Institute of Sweden in 1993; he has been a Professor at the Faculty of Materials Science and Applied Chemistry, Riga Technical University since 2004. Honours and Awards: Corresponding Member of the Latvian Academy of Sciences, 1995; Full Member of the Latvian Academy of Sciences, 1998; Gustavs Vanags Prize of the Latvian Academy of Sciences, 2005; D. H. Grindel Medal (Grindex JSC, Latvia), 2007. Research is focused on NMR spectroscopy. He is the author of more than 500 full papers, theses at conferences, as well as the author of certificates and patents.

Address: 21 Aizkraukles Str., Riga, LV-1006, Latvia

Phone: +37167555985

E-mail: edv@osi.lv

\section{Modris Roze, Valdis Kampars, Kristīne Teivena, Ruta Kampare, Edvards Liepiṇš. Katalītiska glicerīna ēterifikācija ar spirtiem}

Biodīzeļa ražošanā kā blakusprodukts veidojas glicerīns. Sakarā ar biodīzel̦a ražošanas ievērojamu palielināšanu proporcionāli pieaug arī saražotā glicerīna daudzums. Lai gan glicerīnu jau tagad izmanto daudzās tautsaimniecības nozarēs - ķīmiskajā ražošanā, medicīnā un parfirmērijā, tomēr vēl lieli glicerīna apjomi netiek racionāli izmantoti. Tāpēc pasaulē intensīvi meklē jaunus glicerīna izmantošanas veidus. Viens no tādiem varētu būt glicerīna alkilēteru sintēze, kurus varētu izmantot kā piedevu biodīzelim, benzīnam un arī kā šķīinātāju. Literatūrā ir aprakstītas glicerīna alkilēteru iegūšanas reakcijas autoklāvā, izmantojot gan izobutilēnu, gan terc-butanolu.

Mūsu darbā tika pētīta glicerīna alkilēteru iegūšanas iespēja, alkilējot tos ar izopropanolu un terc-butanolu dažādu heterogēno katalizatoru gan stipri skābu jonapmaiņas sveķu, gan ceolīta, gan montmorillonīta mālu klātienē. Reakcija veikta gan bez šķīdinātāja, gan toluola un dioksāna šḳīdumos pie atmosfēras spiediena. Tika konstatēts, ka reakcijā pārsvarā veidojas 1-monoalkilēteri ar nelielu 5-10\% 1,3-diēteru piejaukumu. Ar vakuumdestilācijas un tai sekojošas kolonnu hromatogrāfijas palīdzību izdevās iegūt tīru (98-99\%) 1-izopropoksi-2,3dihidroksipropānu, 1-terc-butoksi-2,3-dihidroksipropānu un 1,3-di-terc-butoksi-2-propanolu. Reakcijā ar terc-butanolu, salīdzinot ar izopropanolu, skābju katalizatoru klātienē tika iegūti augstāki ēteru iznākumi, ko var izskaidrot ar karbkatjona lielāku stabilitāti. Vislabākie terc-butilētera iznākumi (60\%) tika sasniegti toluola šķīdumā katalizatora Amberlyst 36 klātienē. Arī veicot reakciju bez šksīdinātāja vislabākie rezultāti iegūti Amberlyst 36 klātienē. Veicot reakciju bez šksīdinātāja, iznākumi nepārsniedza 35\%, ko var izskaidrot ar katalizatora dezaktivāciju, kas notiek gan ūdens, gan glicerīna ietekmē. Citi katalizatori, gan montmorillonīta māli, gan ceolīts, parādija zemāku katalītisko aktivitāti. Konstatēts, ka ne mikroviḷnu, ne ultraskaņas izmantošana nepalielina glicerīna ēteru iznākumus. Uzņemti un interpretēti ${ }^{1} \mathrm{H}-\mathrm{KMR}$ un ${ }^{13} \mathrm{C}$-KMR 1-izopropoksi-2,3-dihidroksipropānu, 1-terc-butoksi-2,3-dihidroksipropāna un 1,3-di-terc-butoksi-2-propanolu spektri, kurus var izmantot minēto èteru identificēšanai.

\section{Модрис Розе, Валдис Кампарс, Кристине Тейвена, Рута Кампаре, Эдвардс Лиепиньш. Каталитическая этефирикация глицерина со спиртами.}

В качестве побочного продукта в производстве биодизеля образуется глицерин. В связи с существенным увеличением производства биодизельного топлива пропорционально увеличивается количество глицерина. Несмотря на то что, глицерин уже применяется во многих отраслях народного хозяйства - в химической промышленности, медицине и парфюрмерии, большие количество глицерина пока рационально не используются. Поэтому в мире интенсивно ищут новые возможности применения глицерина. Одна из них может быть синтез алкилэфиров глицерина, которые могут быть использованы в качестве добавки в дизельное топливо, бензин и в качестве растворителя. В литературе описаны реакции получения алкилэфиров глицерина автоклаве, используя как изобутилен, так и трет-бутанола.

В нашей работе изучены возможности получения алкилэфиров глицерина, алкилированием глицерина изопропанолом и третбутанолом в присутствии различных гетерогенных катализаторов - как сильно кислых ионообменных смол, цеолита и монтмориллонита. Реакция проводилась, как без растворителя, так и в растворе толуола или диоксана при атмосферном давлении. Было обнаружено, что в реакции в основном образуется 1-моноалкиловий эфир глицерина с небольшой 5-10\% примесью 1,3диалкилого эфира глицерина. После вакуумной перегонки и с последующей колоночной хроматографией, удалось получить 1изопропокси-2,3-дигидроксипропан, 1-трет-бутокси-2,3-дигидроксипропан и 1,3-ди-трет-бутокси-2-пропанол с чистотой 98-99\%. В реакции трет-бутанола с глицерином по сравнению с изопропанолом в присутствии кислотного катализатора получены более высокие выхода алкилэфиров, что можно объяснить большей стабильностью карбкатиона. Лучшие выхода трет-бутилового эфира (60\%) были получены в растворе толуола в присутствии катализатора Amberlyst 36. При проведении реакции алкилирования без растворителя, лучшие результаты были получены при использовании катализатора Amberlyst 36, но выхода не превышали $35 \%$, что можно объяснить инактивацией катализатора, что происходит влиянием воды и глицерина. Другие катализаторы - монтмориллонит и цеолит показали более низкую каталитическую активность. Было установлено, что использование микроволн или ультразвука не увеличивает выход алкилэфиров глицерина. Сняты и интерпретированы ${ }^{1} \mathrm{H}-Я \mathrm{MP}$ и ${ }^{13} \mathrm{C}-Я \mathrm{MP}$ спектра 1-изо-пропокси-2,3дигидроксипропана, 1-трет-бутокси-2,3-дигидроксипропана и 1,3-ди-трет-бутокси-2-пропанола, которые можно использовать для идентификации полученных алкилэфиров. 